CRYSTALLOGRAPHIC COMMUNICATIONS

ISSN 2056-9890

Received 27 August 2019

Accepted 3 September 2019

Edited by A. J. Lough, University of Toronto, Canada

Keywords: crystal structure; quinoline; alkyne; hydrogen bond; $\pi$-stacking; Hirshfeld surface.

CCDC reference: 1951439

Supporting information: this article has supporting information at journals.iucr.org/e

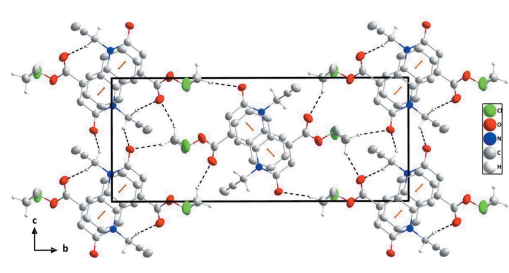

OPEN $\partial$ ACCESS

\section{Crystal structure, Hirshfeld surface analysis and interaction energy and DFT studies of 2-chloroethyl 2-oxo-1-(prop-2-yn-1-yl)-1,2-dihydroquinoline-4- carboxylate}

\author{
Sonia Hayani, ${ }^{*}$ Yassir Filali Baba, ${ }^{a}$ Tuncer Hökelek, ${ }^{b}$ Fouad Ouazzani Chahdi, \\ Joel T. Mague, ${ }^{c}$ Nada Kheira Sebbard and Youssef Kandri Rodi ${ }^{\mathrm{a}}$
}

\begin{abstract}
a Laboratoire de Chimie Organique Appliquée, Université Sidi Mohamed Ben Abdallah, Faculté des Sciences et Techniques, Route d'Immouzzer, BP 2202, Fez, Morocco, 'b Department of Physics, Hacettepe University, 06800 Beytepe, Ankara, Turkey, ${ }^{\mathbf{c}}$ Department of Chemistry, Tulane University, New Orleans, LA 70118, USA, and ${ }^{\mathbf{d}}$ Laboratoire de Chimie Bioorganique Appliquée, Faculté des Sciences, Université Ibn Zohr, Agadir, Morocco. *Correspondence e-mail: soniahayani2018@gmail.com
\end{abstract}

The title compound, $\mathrm{C}_{15} \mathrm{H}_{12} \mathrm{ClNO}_{3}$, consists of a 1,2-dihydroquinoline-4carboxylate unit with 2-chloroethyl and propynyl substituents, where the quinoline moiety is almost planar and the propynyl substituent is nearly perpendicular to its mean plane. In the crystal, the molecules form zigzag stacks along the $a$-axis direction through slightly offset $\pi$-stacking interactions between inversion-related quinoline moieties which are tied together by intermolecular $\mathrm{C}-\mathrm{H}_{\text {Prpnyl }} \cdots \mathrm{O}_{\text {Carbx }}$ and $\mathrm{C}-\mathrm{H}_{\text {Chlethy }} \cdots \mathrm{O}_{\text {Carbx }}$ (Prpnyl = propynyl, Carbx $=$ carboxylate and Chlethy = chloroethyl) hydrogen bonds. The Hirshfeld surface analysis of the crystal structure indicates that the most important contributions for the crystal packing are from $\mathrm{H} \cdots \mathrm{H}(29.9 \%), \mathrm{H} \cdots \mathrm{O} / \mathrm{O} \cdots \mathrm{H}(21.4 \%), \mathrm{H} \cdots \mathrm{C} /$ $\mathrm{C} \cdots \mathrm{H}(19.4 \%), \mathrm{H} \cdots \mathrm{Cl} / \mathrm{Cl} \cdots \mathrm{H}(16.3 \%)$ and $\mathrm{C} \cdots \mathrm{C}(8.6 \%)$ interactions. Hydrogen bonding and van der Waals interactions are the dominant interactions in the crystal packing. Computational chemistry indicates that in the crystal, the $\mathrm{C}-\mathrm{H}_{\text {Prpnyl }} \cdots \mathrm{O}_{\text {Carbx }}$ and $\mathrm{C}-\mathrm{H}_{\text {Chlethy }} \cdots \mathrm{O}_{\text {Carbx }}$ hydrogen bond energies are 67.1 and $61.7 \mathrm{~kJ} \mathrm{~mol}^{-1}$, respectively. Density functional theory (DFT) optimized structures at the B3LYP/ 6-311 G(d,p) level are compared with the experimentally determined molecular structure in the solid state. The HOMO-LUMO behaviour was elucidated to determine the energy gap.

\section{Chemical context}

The quinoline ring system is an important structural unit in naturally occurring quinoline alkaloids, therapeutics and synthetic analogues with interesting biological activities. Quinolone derivatives possess a variety of pharmacological properties such as anti-bacterial (Hu et al., 2017a; Zhang et al., 2018), anti-tubercular (Fan et al., 2018a; Xu et al., 2017), antimalarial (Fan et al., 2018b; Hu et al., 2017b), anti-HIV (Sekgota et al., 2017; Luo et al., 2010), anti-HCV (Mandroni et al., 2014; Cheng et al., 2016) and anti-cancer (Pommier et al., 2010; Shahin et al., 2018; Bisacchi \& Hale, 2016) activities. Recently, substituted quinolines have also been reported to act as antagonists for endothelin (Cheng et al., 1996), 5HT3 (Anzini et al., 1995), NK-3 (Giardina et al., 1997) and leukotriene D4 (Gauthier et al., 1990) receptors. They are also used as inhibitors of gastric $\left(\mathrm{H}^{+} / \mathrm{K}^{+}\right)$-ATPase (Ife et al., 1992), dihydroorotate dehydrogenase (Chen et al., 1990) and 5-lipoxygenase (Musser et al., 1987). As a continuation of our 
research on the development of $N$-substituted quinoline derivatives and the assessments of their potential pharmacological activities (Filali Baba et al., 2016, 2017, 2019; Bouzian et al., 2018, 2019a), we have studied the condensation reaction of propargyl bromide with 2-chloroethyl 2-oxo-1,2-dihydroquinoline-4-carboxylate under phase-transfer catalysis conditions using tetra- $\boldsymbol{n}$-butylammonium bromide (TBAB) as catalyst and potassium carbonate as base. We report herein on the synthesis and the molecular and crystal structures of the title compound along with the Hirshfeld surface analysis and the intermolecular interaction energies and the density functional theory (DFT) computational calculation carried out at the B3LYP/6-311 G(d,p) level.<smiles>C#CCn1c(=O)cc(C(=O)OCCCl)c2ccccc21</smiles>

\section{Structural commentary}

The title molecule consists of a 1,2-dihydroquinoline-4carboxylate unit with 2-chloroethyl and propynyl substituents (Fig. 1). The constituent rings, $A$ (C1-C6) and $B(\mathrm{~N} 1 / \mathrm{C} 1 / \mathrm{C} 6-$ $\mathrm{C} 9$ ), of the dihydroquinoline unit are oriented at a dihedral angle of $2.69(17)^{\circ}$. The mean plane through the dihydroquinoline unit is almost planar with a maximum deviation of 0.040 (3) $\AA$ for atom $\mathrm{N} 1$, and the propynyl substituent is nearly perpendicular to that plane, the $\mathrm{C} 6-\mathrm{N} 1-\mathrm{C} 10-\mathrm{C} 11$ torsion angle being $-79.6(4)^{\circ}$. The carboxyl group is twisted out of coplanarity with the dihydroquinoline unit by a dihedral

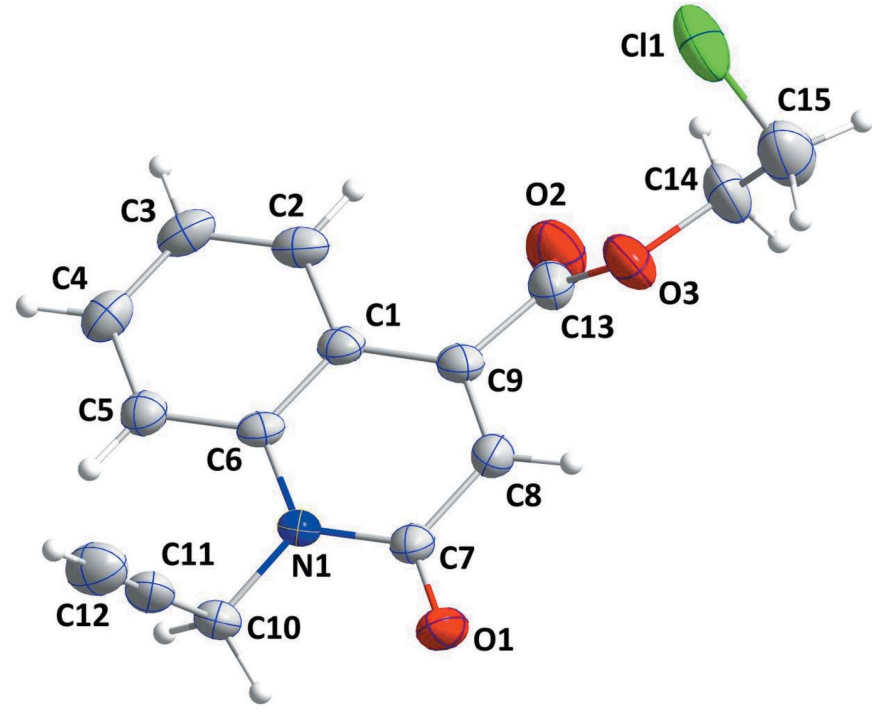

Figure 1

The molecular structure of the title compound with the atom-numbering scheme. Displacement ellipsoids are drawn at the $50 \%$ probability level.
Table 1

Hydrogen-bond geometry $\left(\AA{ }^{\circ}\right)$.

\begin{tabular}{lllll}
\hline$D-\mathrm{H} \cdots A$ & $D-\mathrm{H}$ & $\mathrm{H} \cdots A$ & $D \cdots A$ & $D-\mathrm{H} \cdots A$ \\
\hline $\mathrm{C} 10-\mathrm{H} 10 A \cdots \mathrm{O} 2^{\text {viii }}$ & 0.99 & 2.49 & $3.458(5)$ & 167 \\
$\mathrm{C} 10-\mathrm{H} 10 B \cdots \mathrm{O} 1^{\text {iv }}$ & 0.99 & 2.39 & $3.250(4)$ & 145 \\
$\mathrm{C} 15-\mathrm{H} 15 A \cdots \mathrm{O} 1^{\text {iii }}$ & 0.99 & 2.46 & $3.406(6)$ & 159 \\
$\mathrm{C} 15-\mathrm{H} 15 B \cdots \mathrm{O} 2^{\text {xi }}$ & 0.99 & 2.40 & $3.219(6)$ & 140 \\
\hline
\end{tabular}

Symmetry codes: (iii) $\quad x+\frac{1}{2},-y+\frac{1}{2}, z-\frac{1}{2} ; \quad$ (iv) $\quad-x,-y+1,-z+2$; (viii) $-x,-y+1,-z+1 ;$ (xi) $x+\frac{1}{2},-y+\frac{1}{2}, z+\frac{1}{2}$.

angle of $47.13(23)^{\circ}$; this is also indicated by the $\mathrm{C} 1-\mathrm{C} 9-$ $\mathrm{C} 13-\mathrm{O} 2$ torsion angle of $-44.2(6)^{\circ}$.

\section{Supramolecular features}

In the crystal, the molecules form zigzag stacks along the $a$ axis direction through slightly offset $\pi$-stacking interactions between inversion-related quinoline moieties (Fig. 2). The stacks are tied together by a network of intermolecular $\mathrm{C}-$ $\mathrm{H}_{\text {Prpnyl }} \cdots \mathrm{O}_{\text {Carbx }}$ and $\mathrm{C}-\mathrm{H}_{\text {Chlethy }} \cdots \mathrm{O}_{\text {Carbx }}$ (Prpnyl = propynyl, Carbx $=$ carboxylate and Chlethy $=$ chloroethyl) hydrogen

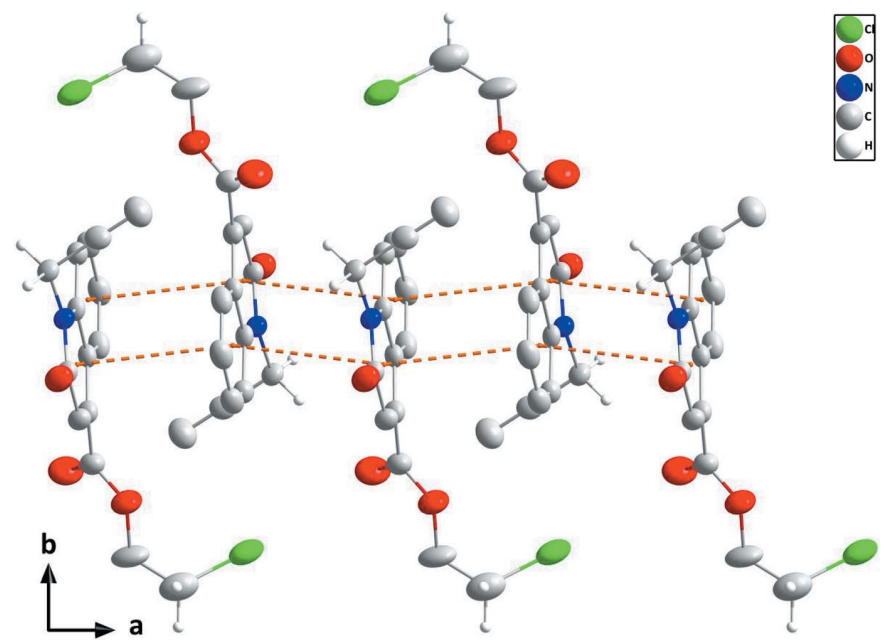

Figure 2

A partial packing diagram viewed along the $c$-axis direction with the $\pi$ stacking interactions shown as dashed lines.

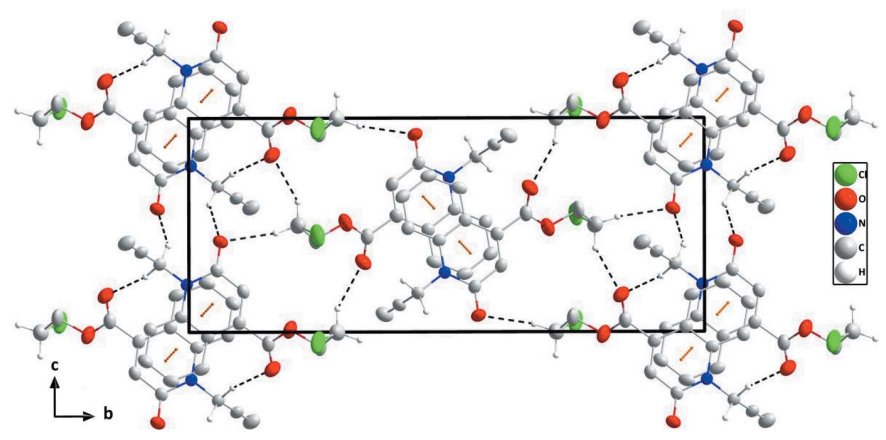

Figure 3

A partial packing diagram viewed along the $a$-axis direction with the $\mathrm{C}-$ $\mathrm{H}_{\text {Prpnyl }} \cdots \mathrm{O}_{\text {Carbx }}$ and $\mathrm{C}-\mathrm{H}_{\text {Chlethy }} \cdots \mathrm{O}_{\text {Carbx }}$ (Prpnyl = propynyl, Carbx $=$ carboxylate and Chlethy $=$ chloroethyl) hydrogen bonds and $\pi$-stacking interactions shown, respectively, as black and orange dashed lines. 
Table 2

Selected interatomic distances $(\AA)$.

\begin{tabular}{llll}
\hline $\mathrm{Cl} 1 \cdots \mathrm{O} 3$ & $3.110(3)$ & $\mathrm{C} 1 \cdots \mathrm{C} 6^{\text {viii }}$ & $3.534(5)$ \\
$\mathrm{C} 1 \cdots \mathrm{C} 12^{\mathrm{i}}$ & $3.629(5)$ & $\mathrm{C} 2 \cdots \mathrm{C} 6^{\mathrm{ii}}$ & $3.489(5)$ \\
$\mathrm{Cl} 1 \cdots \mathrm{H} 12^{\mathrm{i}}$ & 2.75 & $\mathrm{C} 2 \cdots \mathrm{C} 10^{\text {viii }}$ & $3.388(5)$ \\
$\mathrm{Cl} 1 \cdots \mathrm{H} 5^{\mathrm{ii}}$ & 3.03 & $\mathrm{C} 4 \cdots \mathrm{C} 7^{\text {viii }}$ & $3.597(5)$ \\
$\mathrm{Cl} 1 \cdots \mathrm{H} 8^{\text {iii }}$ & 2.96 & $\mathrm{C} 4 \cdots \mathrm{C} 9^{\mathrm{ii}}$ & $3.452(5)$ \\
$\mathrm{O} 1 \cdots \mathrm{C} 10^{\text {iv }}$ & $3.250(5)$ & $\mathrm{C} 5 \cdots \mathrm{C} 11$ & $3.241(5)$ \\
$\mathrm{O} 1 \cdots \mathrm{C} 12^{\text {v }}$ & $3.409(6)$ & $\mathrm{C} 5 \cdots \mathrm{C} 9^{\text {viii }}$ & $3.575(5)$ \\
$\mathrm{O} 1 \cdots \mathrm{C} 15^{\text {vi }}$ & $3.406(5)$ & $\mathrm{C} 6 \cdots \mathrm{C} 6^{\text {viii }}$ & $3.485(4)$ \\
$\mathrm{O} 2 \cdots \mathrm{C} 2$ & $3.045(5)$ & $\mathrm{C} 2 \cdots \mathrm{H} 10 A^{\text {viii }}$ & 2.88 \\
$\mathrm{O} 2 \cdots \mathrm{C} 15^{\text {vii }}$ & $3.219(6)$ & $\mathrm{C} 5 \cdots \mathrm{H} 10 A$ & 2.61 \\
$\mathrm{O} 3 \cdots \mathrm{C} 11$ & $3.110(3)$ & $\mathrm{C} 10 \cdots \mathrm{H} 5$ & 2.50 \\
$\mathrm{O} 1 \cdots \mathrm{H} 10 B$ & 2.30 & $\mathrm{C} 11 \cdots \mathrm{H} 3^{\text {ix }}$ & 2.85 \\
$\mathrm{O} 1 \cdots \mathrm{H} 10 B^{\text {iv }}$ & 2.39 & $\mathrm{C} 11 \cdots \mathrm{H} 5$ & 2.72 \\
$\mathrm{O} 1 \cdots \mathrm{H} 15 A^{\text {vi }}$ & 2.46 & $\mathrm{C} 12 \cdots \mathrm{H} 14 A^{\mathrm{x}}$ & 2.95 \\
$\mathrm{O} 2 \cdots \mathrm{H} 14 B$ & 2.46 & $\mathrm{C} 12 \cdots \mathrm{H} 2^{\mathrm{ii}}$ & 2.80 \\
$\mathrm{O} 2 \cdots \mathrm{H} 2$ & 2.49 & $\mathrm{C} 12 \cdots \mathrm{H} 3^{\text {ix }}$ & 2.93 \\
$\mathrm{O} 2 \cdots \mathrm{H} 14 A$ & 2.80 & $\mathrm{C} 13 \cdots \mathrm{H} 2$ & 2.65 \\
$\mathrm{O} 2 \cdots \mathrm{H} 15 B^{\text {vii }}$ & 2.40 & $\mathrm{H} 5 \cdots \mathrm{H} 10 A$ & 2.10 \\
$\mathrm{O} 2 \cdots \mathrm{H} 10 A^{\text {viii }}$ & 2.49 & $\mathrm{H} 8 \cdots \mathrm{H} 15 A^{\text {vi }}$ & 2.55 \\
$\mathrm{O} 3 \cdots \mathrm{H} 8$ & 2.50 & & \\
\hline
\end{tabular}

Symmetry codes: (i) $-x+\frac{3}{2}, y-\frac{1}{2},-z+\frac{3}{2}$; $\quad$ (ii) $-x+1,-y+1,-z+1$; $x+\frac{1}{2},-y+\frac{1}{2}, z-\frac{1}{2} ; \quad$ (iv) $-x,-y+1,-z+2 ; \quad$ (v) $-x+1,-y+1,-z+2$; $\quad$ (vi)

bonds, enclosing $R_{2}^{2}(16)$ and $R_{4}^{4}(8)$ ring motifs (Table 1 and Fig. 3). The $\pi-\pi$ contacts between the constituent rings, $A$ (C1-C6) and $B(\mathrm{~N} 1 / \mathrm{C} 1 / \mathrm{C} 6-\mathrm{C} 9)$, of the dihydroquinoline unit, $C g 2 \cdots C g 1^{\mathrm{i}}, C g 2 \cdots C g 1^{\mathrm{ii}}$ and $C g 1 \cdots C g 1^{\mathrm{i}}$ [centroid-centroid distance $=3.728(2), 3.571$ (2) and 3.761 (2) $\AA$, respectively, where $C g 1$ and $C g 2$ are the centroids of the rings, $A$ and $B$; symmetry codes: (i) $1-x, 1-y, 1-z$ and (ii) $-x, 1-y, 1-z]$, may further stabilize the structure.

\section{Hirshfeld surface analysis}

In order to visualize the intermolecular interactions in the crystal of the title compound, a Hirshfeld surface (HS)

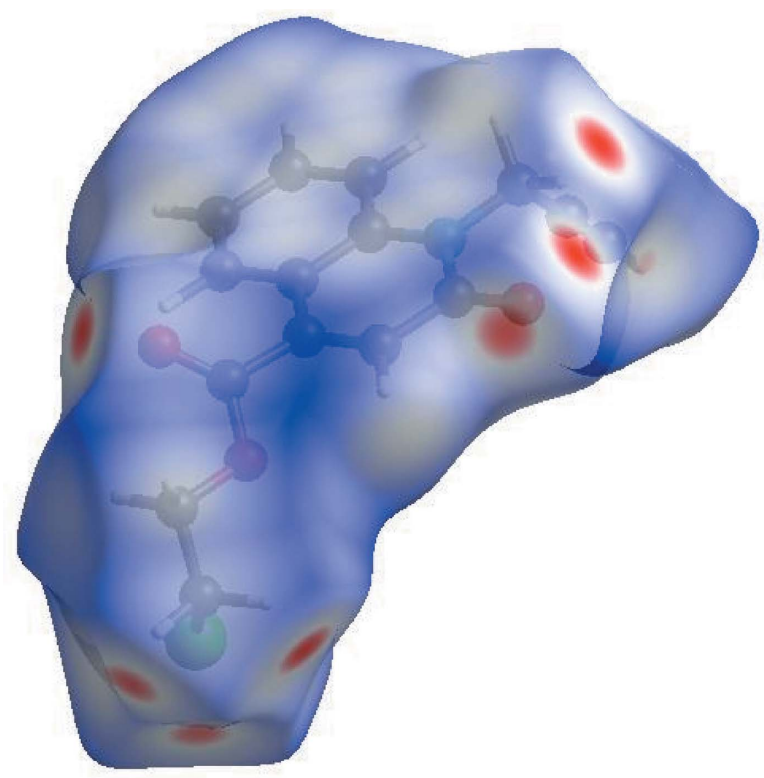

Figure 4

View of the three-dimensional Hirshfeld surface of the title compound plotted over $d_{\text {norm }}$ in the range -0.2177 to 1.3626 a.u.

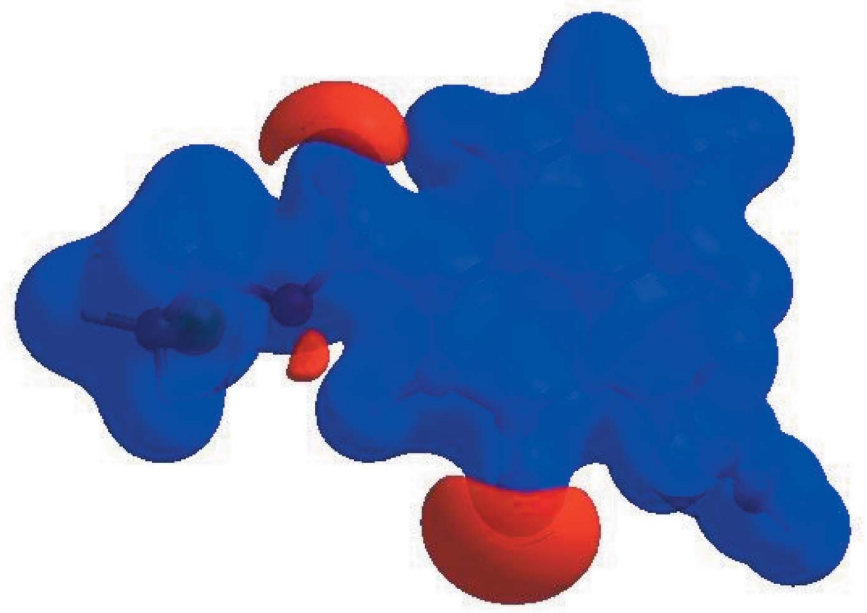

Figure 5

View of the three-dimensional Hirshfeld surface of the title compound plotted over electrostatic potential energy in the range -0.0500 to 0.0500 a.u. using the STO-3 G basis set at the Hartree-Fock level of theory. Hydrogen-bond donors and acceptors are shown as blue and red regions around the atoms, corresponding to positive and negative potentials, respectively.

analysis (Hirshfeld, 1977; Spackman \& Jayatilaka, 2009) was carried out by using CrystalExplorer17.5 (Turner et al., 2017). In the HS plotted over $d_{\text {norm }}$ (Fig. 4), the white surface indicates contacts with distances equal to the sum of van der Waals radii, and the red and blue colours indicate distances shorter (in close contact) or longer (distinct contact) than the van der Waals radii, respectively (Venkatesan et al., 2016). The brightred spots appearing near atoms $\mathrm{O} 1, \mathrm{O} 2$ and hydrogen atoms $\mathrm{H} 10 A, \mathrm{H} 10 B, \mathrm{H} 15 A$ and $\mathrm{H} 15 B$ indicate their roles as the respective donors and/or acceptors; they also appear as blue and red regions corresponding to positive and negative potentials on the HS mapped over electrostatic potential (Spackman et al., 2008; Jayatilaka et al., 2005) as shown in

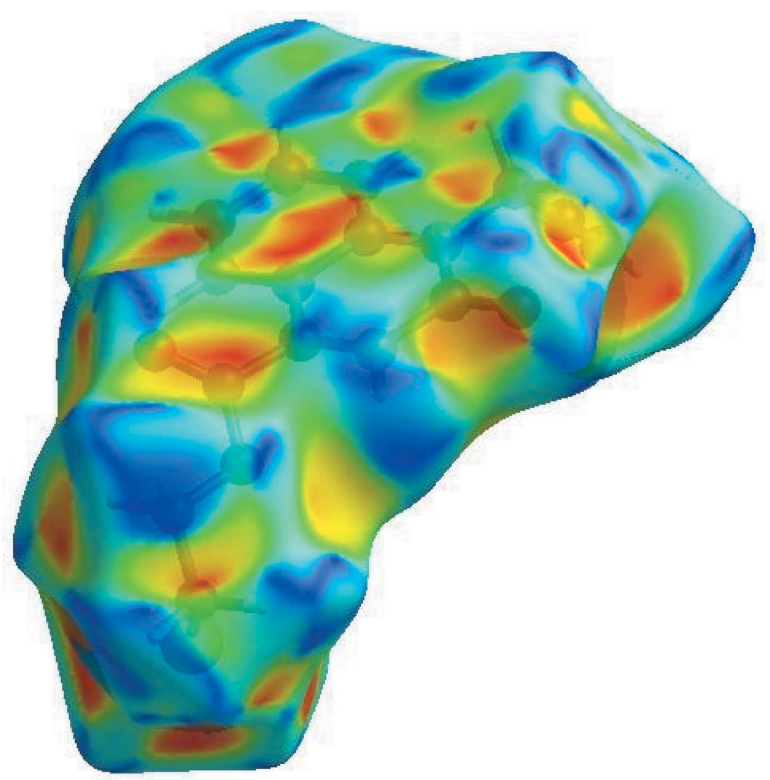

Figure 6

Hirshfeld surface of the title compound plotted over shape-index. 
Fig. 5. The blue regions indicate the positive electrostatic potential (hydrogen-bond donors), while the red regions indicate the negative electrostatic potential (hydrogen-bond acceptors). The shape-index of the HS is a tool to visualize $\pi-$ $\pi$ stacking by the presence of adjacent red and blue triangles; if there are no adjacent red and/or blue triangles, then there are no $\pi-\pi$ interactions. Fig. 6 clearly suggest that there are $\pi-$ $\pi$ interactions in (I).

The overall two-dimensional fingerprint plot, Fig. $7 a$, and those delineated into $\mathrm{H} \cdots \mathrm{H}, \mathrm{H} \cdots \mathrm{O} / \mathrm{O} \cdots \mathrm{H}, \mathrm{H} \cdots \mathrm{C} / \mathrm{C} \cdots \mathrm{H}$, $\mathrm{H} \cdots \mathrm{Cl} / \mathrm{Cl} \cdots \mathrm{H}, \mathrm{C} \cdots \mathrm{C}, \mathrm{C} \cdots \mathrm{N} / \mathrm{N} \cdots \mathrm{C}$ and $\mathrm{O} \cdots \mathrm{Cl} / \mathrm{Cl} \cdots \mathrm{O}$ contacts (McKinnon et al., 2007) are illustrated in Fig. $7 b-h$, respectively, together with their relative contributions to the
Hirshfeld surface. The most important interaction is $\mathrm{H} \cdots \mathrm{H}$ (Table 2), contributing $29.9 \%$ to the overall crystal packing, which is reflected in Fig. $7 b$ as widely scattered points of high density due to the large hydrogen content of the molecule with the tip at $d_{\mathrm{e}}=d_{\mathrm{i}}=1.22 \AA$. The pair of characteristic wings in the fingerprint plot delineated into $\mathrm{H} \cdots \mathrm{O} / \mathrm{O} \cdots \mathrm{H}$ contacts (21.4\% contribution, Fig. $7 c$ ) are viewed as a pair of spikes with the tips at $d_{\mathrm{e}}+d_{\mathrm{i}}=2.28 \AA$. In the absence of $\mathrm{C}-\mathrm{H} \cdots \pi$ interactions, the pairs of characteristic wings in Fig. $7 d$ arise from $\mathrm{H} \cdots \mathrm{C} / \mathrm{C} \cdots \mathrm{H}$ contacts $(19.4 \%)$ and are viewed as pairs of spikes with the tips at $d_{\mathrm{e}}+d_{\mathrm{i}}=2.65 \AA$ and $2.70 \AA$ for the thin and thick spikes, respectively. The scattered points in the pair of wings in the fingerprint plot delineated into $\mathrm{H} \cdots \mathrm{Cl} / \mathrm{Cl} \cdots \mathrm{H}$
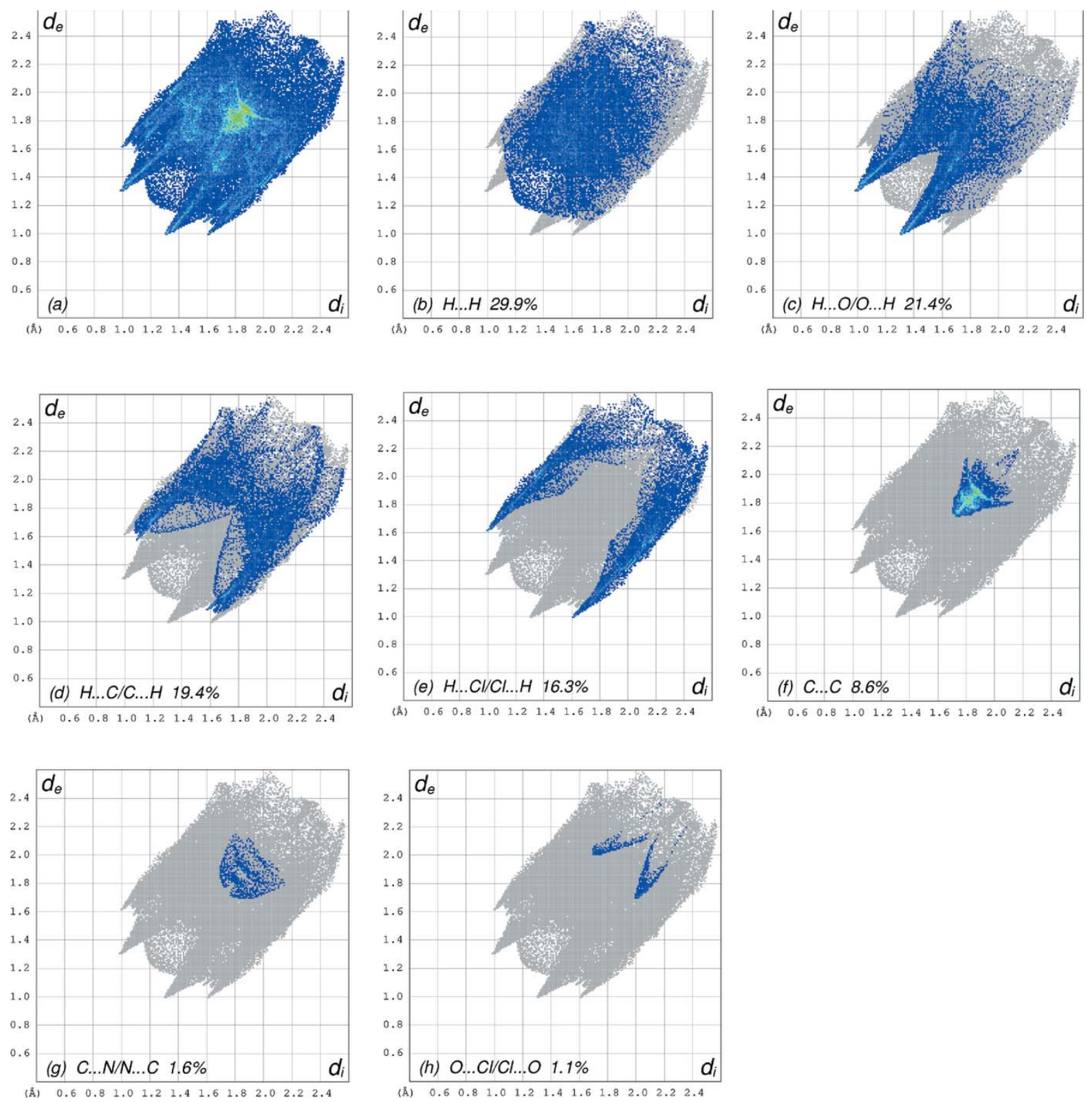

Figure 7

The full two-dimensional fingerprint plots for the title compound, showing $(a)$ all interactions, and delineated into $(b) \mathrm{H} \cdots \mathrm{H},(c) \mathrm{H} \cdots \mathrm{O} / \mathrm{O} \cdots \mathrm{H},(d)$ $\mathrm{H} \cdots \mathrm{C} / \mathrm{C} \cdots \mathrm{H},(e) \mathrm{H} \cdots \mathrm{Cl} / \mathrm{Cl} \cdots \mathrm{H},(f) \mathrm{C} \cdots \mathrm{C},(g) \mathrm{C} \cdots \mathrm{N} / \mathrm{N} \cdots \mathrm{C}$ and $(h) \mathrm{O} \cdots \mathrm{Cl} / \mathrm{Cl} \cdots \mathrm{O}$ interactions. The $\mathrm{d}_{\mathrm{i}}$ and $\mathrm{d}_{\mathrm{e}}$ values are the closest internal and external distances (in $\AA$ ) from given points on the Hirshfeld surface contacts. 
Table 3

Comparison of selected (X-ray and DFT) geometric data $\left(\AA{ }^{\circ}\right)$.

\begin{tabular}{lll}
\hline Bonds/angles & X-ray & B3LYP/6-311G(d,p) \\
\hline Cl1-C15 & $1.838(6)$ & 1.88121 \\
O1-C7 & $1.235(5)$ & 1.25852 \\
O2-C13 & $1.213(5)$ & 1.24099 \\
O3-C13 & $1.322(5)$ & 1.38771 \\
O3-C14 & $1.459(5)$ & 1.47976 \\
N1-C7 & $1.381(5)$ & 1.40545 \\
N1-C6 & $1.405(4)$ & 1.41686 \\
N1-C10 & $1.469(4)$ & 1.49984 \\
C13-O3-C14 & $115.2(4)$ & 116.83182 \\
C7-N1-C6 & $123.1(3)$ & 121.89630 \\
C7-N1-C10 & $116.9(3)$ & 117.96161 \\
C6-N1-C10 & $120.0(3)$ & 120.53011 \\
N1-C6-C1 & $119.5(3)$ & 122.42582 \\
O1-C7-N1 & $121.4(3)$ & 121.61064 \\
O1-C7-C8 & $122.5(3)$ & 115.96268 \\
N1-C7-C8 & $116.1(3)$ & \\
\hline
\end{tabular}

(16.3\% contribution, Fig. $7 e$ ) have a symmetrical distribution with the edges at $d_{\mathrm{e}}+d_{\mathrm{i}}=2.60 \AA$. The C $\cdots \mathrm{C}$ contacts, Fig. $7 f$, have an arrow-shaped distribution of points with the tip at $d_{\mathrm{e}}=$ $d_{\mathrm{i}}=1.72 \AA$. Finally, the characteristic tip and wings in the fingerprint plots delineated into $\mathrm{C} \cdots \mathrm{N} / \mathrm{N} \cdots \mathrm{C}$ and $\mathrm{O} \cdots \mathrm{Cl}$ / $\mathrm{Cl}$. . O contacts $(1.6 \%$ and $1.1 \%$ contributions, respectively, Fig. $7 g$ and $7 h$ ) have the tips at $d_{\mathrm{e}}=d_{\mathrm{i}}=1.73$ and $3.70 \AA$, respectively.

The Hirshfeld surface representations with the function $d_{\text {norm }}$ plotted onto the surface are shown for the $\mathrm{H} \cdots \mathrm{H}$, $\mathrm{H} \cdots \mathrm{O} / \mathrm{O} \cdots \mathrm{H}, \mathrm{H} \cdots \mathrm{C} / \mathrm{C} \cdot \mathrm{H}$ and $\mathrm{H} \cdots \mathrm{Cl} / \mathrm{Cl} \cdots \mathrm{H}$ interactions in Fig. $8 a-d$, respectively.

The Hirshfeld surface analysis confirms the importance of $\mathrm{H}$-atom contacts in establishing the packing. The large number
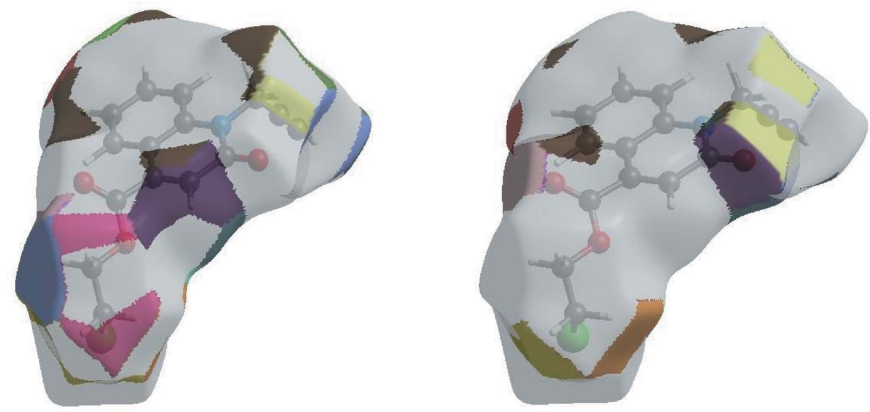

(a)

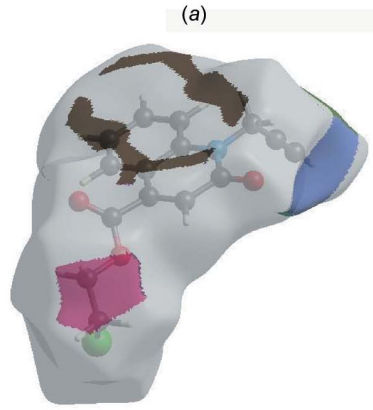

(c)

Figure 8

The Hirshfeld surface representations with the function $d_{\text {norm }}$ plotted onto the surface for $(a) \mathrm{H} \cdots \mathrm{H},(b) \mathrm{H} \cdots \mathrm{O} / \mathrm{O} \cdots \mathrm{H}$, (c) $\mathrm{H} \cdots \mathrm{C} / \mathrm{C} \cdots \mathrm{H}$ and (d) $\mathrm{H} \cdots \mathrm{Cl} / \mathrm{Cl} \cdots \mathrm{H}$ interactions.
Table 4

Calculated energies.

Molecular Energy

Total Energy, $T E$

$\mathrm{E}_{\text {HOMO }}(\mathrm{eV})$

$\mathrm{E}_{\text {LUMO }}(\mathrm{eV})$

Gap $\Delta E(\mathrm{eV})$

Dipole moment, $\mu$ (Debye)

Ionization potential, $I(\mathrm{eV})$

Electron affinity, $A$

Electro negativity, $\chi$

Hardness, $\eta$

Electrophilicity index, $\omega$

Softness, $\sigma$

Fraction of electron transferred, $\Delta N$

$-35893.2971$

$-6.3024$

$-2.6040$

3.6984

3.8441

6.3024

2.6040

4.4532

1.8492

5.3620

0.5408

0.6886

of $\mathrm{H} \cdots \mathrm{H}, \mathrm{H} \cdots \mathrm{O} / \mathrm{O} \cdots \mathrm{H}, \mathrm{H} \cdots \mathrm{C} / \mathrm{C} \cdots \mathrm{H}$ and $\mathrm{H} \cdots \mathrm{Cl} / \mathrm{Cl} \cdots \mathrm{H}$ interactions suggest that van der Waals interactions and hydrogen bonding play the major roles in the crystal packing (Hathwar et al., 2015).

\section{Interaction energy calculations}

The intermolecular interaction energies were calculated using the CE-B3LYP/6-31G(d,p) energy model available in CrystalExplorer17.5 (Turner et al., 2017), where by default a cluster of molecules are generated by applying crystallographic symmetry operations with respect to a selected central molecule within a radius of $3.8 \AA$ (Turner et al., 2014). The total intermolecular energy $\left(E_{\text {tot }}\right)$ is the sum of electrostatic $\left(E_{\text {ele }}\right)$, polarization $\left(E_{\mathrm{pol}}\right)$, dispersion $\left(E_{\mathrm{dis}}\right)$ and exchange-repulsion $\left(E_{\mathrm{rep}}\right)$ energies (Turner et al., 2015) with scale factors of 1.057, $0.740,0.871$ and 0.618, respectively (Mackenzie et al., 2017). Hydrogen-bonding interaction energies (in $\mathrm{kJ} \mathrm{mol}^{-1}$ ) were calculated to be $-25.2\left(E_{\text {ele }}\right),-2.1\left(E_{\text {pol }}\right),-85.4\left(E_{\text {dis }}\right), 57.5$ $\left(E_{\text {rep }}\right)$ and $-67.1\left(E_{\text {tot }}\right)$ for the $\mathrm{C}-\mathrm{H}_{\text {Prpnyl }} \cdots \mathrm{O}_{\mathrm{Carbx}}$ hydrogen bond and $-26.5\left(E_{\text {ele }}\right),-4.7\left(E_{\mathrm{pol}}\right),-73.2\left(E_{\mathrm{dis}}\right), 54.3\left(E_{\mathrm{rep}}\right)$ and $-61.7\left(E_{\text {tot }}\right)$ for the $\mathrm{C}-\mathrm{H}_{\text {Chlethy }} \cdots \mathrm{O}_{\text {Carbx }}$ hydrogen bond.

\section{DFT calculations}

The optimized structure of the title compound in the gas phase was generated theoretically via density functional theory (DFT) using the standard B3LYP functional and 6-311 G(d,p) basis-set calculations (Becke, 1993) as implemented in GAUSSIAN 09 (Frisch et al., 2009). The theoretical and experimental results were in good agreement (Table 3). The highest-occupied molecular orbital (HOMO), acting as an electron donor, and the lowest-unoccupied molecular orbital (LUMO), acting as an electron acceptor, are very important parameters for quantum chemistry. When the energy gap is small, the molecule is highly polarizable and has high chemical reactivity. The DFT calculations provide some important information on the reactivity and site selectivity of the molecular framework. $E_{\mathrm{HOMO}}$ and $E_{\mathrm{LUMO}}$ clarify the inevitable charge-exchange collaboration inside the studied material, and are recorded in Table 4 along with the electronegativity $(\chi)$, hardness $(\eta)$, potential $(\mu)$, electrophilicity $(\omega)$ and soft- 


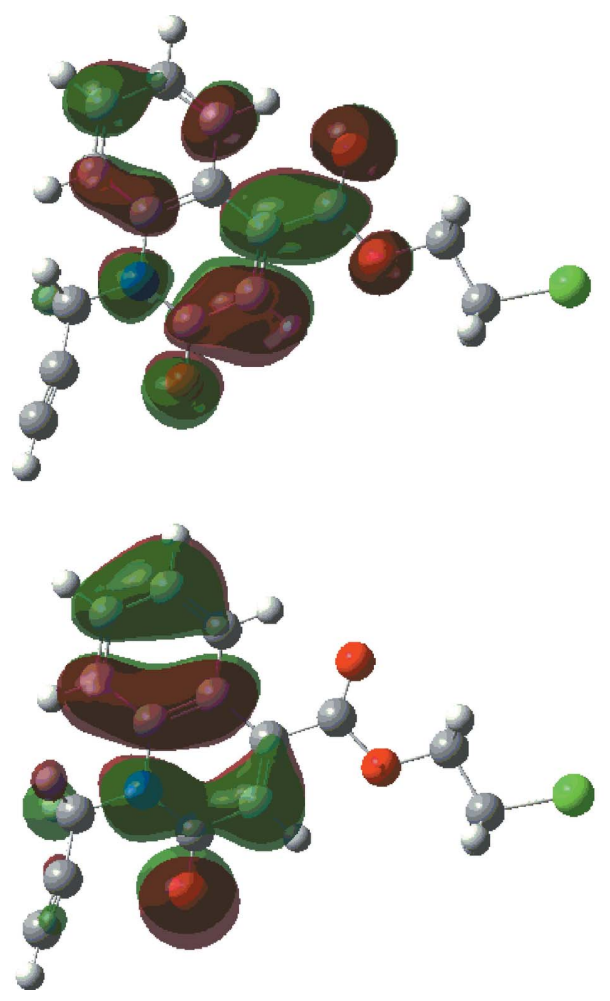

Figure 9

The energy band gap of the title compound.

ness $(\sigma)$. The significance of $\eta$ and $\sigma$ is to evaluate both the reactivity and stability. The electron transition from the HOMO to the LUMO energy level is shown in Fig. 9. The HOMO and LUMO are localized in the plane extending from the whole 2-chloroethyl 2-oxo-1-(prop-2-yn-1-yl)-1,2-dihydroquinoline-4-carboxylate ring. The energy band gap $[\Delta E$ $\left.=E_{\mathrm{LUMO}}-E_{\mathrm{HOMO}}\right]$ of the molecule is $3.6984 \mathrm{eV}$, and the frontier molecular orbital energies, $E_{\text {HOMO }}$ and $E_{\text {LUMO }}$ are -6.3024 and $-2.6040 \mathrm{eV}$, respectively.

\section{Database survey}

A non-alkylated analogue, namely quinoline and its derivatives, has been reported (Filali Baba et al., 2016, 2017), as well as three similar structures, see: Bouzian et al., 2018, 2019a,b; Filali Baba et al., 2019.

\section{Synthesis and crystallization}

To a solution of 2-chloroethyl 2-oxo-1,2-dihydroquinoline-4carboxylate $(0.50 \mathrm{~g}, 2.00 \mathrm{mmol})$ in $\mathrm{DMF}(10.00 \mathrm{ml})$ were added propargyl bromide $(0.20 \mathrm{ml}, 2.38 \mathrm{mmol}), \mathrm{K}_{2} \mathrm{CO}_{3}$ $(0.82 \mathrm{~g}, 6.00 \mathrm{mmol})$ and TBAB $(0.06 \mathrm{~g}, 0.20 \mathrm{mmol})$. The reaction mixture was stirred at room temperature for $6 \mathrm{~h}$. After removal of the salts by filtration, the solvent was evaporated under reduced pressure and the resulting residue was dissolved in dichloromethane. The organic phase was dried with $\mathrm{Na}_{2} \mathrm{SO}_{4}$, and then concentrated under reduced pressure. The pure compound was obtained by column chro-
Table 5

Experimental details.
Crystal data

Chemical formula

$M_{\text {r }}$

Crystal system, space group

Temperature (K)

$a, b, c(\AA)$

$\beta\left({ }^{\circ}\right)$

$V\left(\AA^{3}\right)$

Z

Radiation type

$\mu\left(\mathrm{mm}^{-1}\right)$

Crystal size (mm)

Data collection

Diffractometer

Absorption correction

$T_{\min }, T_{\max }$

No. of measured, independent and observed $[I>2 \sigma(I)]$ reflections

$R_{\text {int }}$

$(\sin \theta / \lambda)_{\max }\left(\AA^{-1}\right)$

Refinement

$R\left[F^{2}>2 \sigma\left(F^{2}\right)\right], w R\left(F^{2}\right), S$

No. of reflections

No. of parameters

$\mathrm{H}$-atom treatment

$\Delta \rho_{\max }, \Delta \rho_{\min }\left(\mathrm{e} \AA^{-3}\right)$
$\mathrm{C}_{15} \mathrm{H}_{12} \mathrm{ClNO}_{3}$

289.71

Monoclinic, $P 2_{1} / n$

150

7.1809 (2), 21.4466 (5), 8.9173 (2)

$92.784(2)$

$\mathrm{Cu} K \alpha$

2.53

$0.19 \times 0.14 \times 0.01$

Bruker D8 VENTURE PHOTON 100 CMOS

Multi-scan ( $S A D A B S$; Krause et al., 2015)

$0.64,0.97$

10119, 2555, 2170

0.047

0.610

$0.078,0.178,1.13$

2555

181

$\mathrm{H}$-atom parameters constrained $0.73,-0.35$
$1371.70(6)$

Computer programs: APEX3 and SAINT (Bruker, 2016), SHELXT (Sheldrick, 2015a), SHELXL2018 (Sheldrick, 2015b), DIAMOND (Brandenburg \& Putz, 2012) and SHELXTL (Sheldrick, 2008).

matography using hexane/ethyl acetate (3/1) as eluent. The isolated solid was recrystallized from hexane/ethyl acetate (3:1) to afford colourless crystals (yield: 84\%, m.p. $394.15 \mathrm{~K}$ ).

\section{Refinement}

Crystal data, data collection and structure refinement details are summarized in Table 5. Hydrogen atoms were positioned geometrically $\left(\mathrm{C}-\mathrm{H}=0.95\right.$ and $0.99 \AA$, for $\mathrm{CH}$ and $\mathrm{CH}_{2} \mathrm{H}$ atoms, respectively) and constrained to ride on their parent atoms, with $U_{\text {iso }}(\mathrm{H})=1.2 U_{\text {eq }}(\mathrm{C})$. The largest peak and hole in the final difference map are $+0.73 \mathrm{e}^{-3}(1.00 \AA$ away from Cl1) and $-0.35 \mathrm{e}^{-3}$ (0.64 $\AA$ away from $\left.\mathrm{C} 14\right)$, and are associated with the 2-chloroethylcarboxy group and may indicate a slight degree of disorder here but it was not considered serious enough to model.

\section{Funding information}

The support of NSF-MRI grant No. 1228232 for the purchase of the diffractometer and Tulane University for support of the Tulane Crystallography Laboratory are gratefully acknowledged. $\mathrm{TH}$ is grateful to Hacettepe University Scientific Research Project Unit (grant No. 013 D04 602 004). 


\section{References}

Anzini, M., Cappelli, A., Vomero, S., Giorgi, G., Langer, T., Hamon, M., Merahi, N., Emerit, B. M., Cagnotto, A., Skorupska, M., Mennini, T. \& Pinto, J. C. (1995). J. Med. Chem. 38, 2692-2704.

Becke, A. D. (1993). J. Chem. Phys. 98, 5648-5652.

Bisacchi, G. S. \& Hale, M. R. (2016). Curr. Med. Chem. 23, 520-577.

Bouzian, Y., Faizi, M. S. H., Mague, J. T., Otmani, B. E., Dege, N., Karrouchi, K. \& Essassi, E. M. (2019a). Acta Cryst. E75, 980-983.

Bouzian, Y., Hlimi, F., Sebbar, N. K., El Hafi, M., Hni, B., Essassi, E. M. \& Mague, J. T. (2018). IUCrData, 3, x181438.

Bouzian, Y., Karrouchi, K., Anouar, E. H., Bouhfid, R., Arshad, S. \& Essassi, E. M. (2019b). Acta Cryst. E75, 912-916.

Brandenburg, K. \& Putz, H. (2012). DIAMOND, Crystal Impact GbR, Bonn, Germany.

Bruker (2016). APEX3, SAINT and SADABS. Bruker AXS, Inc., Madison, Wisconsin, USA.

Chen, S. F., Papp, L. M., Ardecky, R. J., Rao, G. V., Hesson, D. P., Forbes, M. \& Desxter, D. L. (1990). Biochem. Pharmacol. 40, 709714.

Cheng, X. M., Lee, C., Klutchko, S., Winters, T., Reynolds, E. E., Welch, K. M., Flynn, M. A. \& Doherty, A. M. (1996). Bioorg. Med. Chem. Lett. 6, 2999-3002.

Cheng, Y., Shen, J., Peng, R. Z., Wang, G. F., Zuo, J. P. \& Long, Y. Q. (2016). Bioorg. Med. Chem. Lett. 26, 2900-2906.

Fan, Y. L., Cheng, X. W., Wu, J. B., Liu, M., Zhang, F. Z., Xu, Z. \& Feng, L. S. (2018b). Eur. J. Med. Chem. 146, 1-14.

Fan, Y. L., Wu, J. B., Cheng, X. W., Zhang, F. Z. \& Feng, L. S. (2018a). Eur. J. Med. Chem. 146, 554-563.

Filali Baba, Y., Elmsellem, H., Kandri Rodi, Y., Steli, H. A. D. C., Ouzidan, Y., Ouazzani Chahdi, F., Sebbar, N. K., Essassi, E. M. \& Hammouti, B. (2016). Pharma Chemica, 8, 159-169.

Filali Baba, Y., Kandri Rodi, Y., Ouzidan, Y., Mague, J. T., Ouazzani Chahdi, F. \& Essassi, E. M. (2017). IUCrData, 2, x171038.

Filali Baba, Y., Sert, Y., Kandri Rodi, Y., Hayani, S., Mague, J. T., Prim, D., Marrot, J., Ouazzani Chahdi, F., Sebbar, N. K. \& Essassi, E. M. (2019). J. Mol. Struct. 1188, 255-268.

Frisch, M. J., Trucks, G. W., Schlegel, H. B., Scuseria, G. E., Robb, M. A., Cheeseman, J. R., et al. (2009). GAUSSIAN09. Gaussian Inc., Wallingford, CT, USA.

Gauthier, J. Y., Jones, T., Champion, E., Charette, L., Dehaven, R., Ford-Hutchinson, A. W., Hoogsteen, K., Lord, A., Masson, P., Piechuta, H., Pong, S. S., Springer, J. P., Therien, M., Zamboni, R. \& Young, R. N. (1990). J. Med. Chem. 33, 2841-2845.

Giardina, G. A. M., Sarau, H. M., Farina, C., Medhurst, A. D., Grugni, M., Raveglia, L. F., Schmidt, D. B., Rigolio, R., Luttmann, M., Vecchietti, V. \& Hay, D. W. P. (1997). J. Med. Chem. 40, 1794-1807.

Hathwar, V. R., Sist, M., Jørgensen, M. R. V., Mamakhel, A. H., Wang, X., Hoffmann, C. M., Sugimoto, K., Overgaard, J. \& Iversen, B. B. (2015). IUCrJ, 2, 563-574.

Hirshfeld, H. L. (1977). Theor. Chim. Acta, 44, 129-138.

Hu, Y. Q., Gao, C., Zhang, S., Xu, L., Xu, Z., Feng, L. S., Wu, X. \& Zhao, F. (2017b). Eur. J. Med. Chem. 139, 22-47.
Hu, Y. Q., Zhang, S., Xu, Z., Lv, Z. S., Liu, M. L. \& Feng, L. S. (2017a). Eur. J. Med. Chem. 141, 335-345.

Ife, K. J., Brown, T. H., Keeling, D. J., Leach, C. A., Meeson, M. L., Parsons, M. E., Reavill, D. R., Theobald, C. J. \& Wiggall, K. (1992). J. Med. Chem. 35, 3413-3422.

Jayatilaka, D., Grimwood, D. J., Lee, A., Lemay, A., Russel, A. J., Taylor, C., Wolff, S. K., Cassam-Chenai, P. \& Whitton, A. (2005). TONTO - A System for Computational Chemistry. Available at: http://hirshfeldsurface.net/

Krause, L., Herbst-Irmer, R., Sheldrick, G. M. \& Stalke, D. (2015). J. Appl. Cryst. 48, 3-10.

Luo, Z. G., Tan, J. J., Zeng, Y., Wang, C. X. \& Hu, L. M. (2010). Mini Rev. Med. Chem. 10, 1046-1057.

Mackenzie, C. F., Spackman, P. R., Jayatilaka, D. \& Spackman, M. A. (2017). IUCrJ, 4, 575-587.

Manfroni, G., Cannalire, R., Barreca, M. L., Kaushik-Basu, N., Leyssen, P., Winquist, J., Iraci, N., Manvar, D., Paeshuyse, J., Guhamazumder, R., Basu, A., Sabatini, S., Tabarrini, O., Danielson, U. H., Neyts, J. \& Cecchetti, V. (2014). J. Med. Chem. 57, $1952-$ 1963.

McKinnon, J. J., Jayatilaka, D. \& Spackman, M. A. (2007). Chem. Commun. pp. 3814-3816.

Musser, J. H., Chakraborty, U. R., Sciortino, S., Gordon, R. J., Khandwala, A., Neiss, E. S., Pruss, T. P., Van Inwegen, R., Weinryb, I. \& Coutts, S. M. (1987). J. Med. Chem. 30, 96-104.

Pommier, Y., Leo, E., Zhang, H. L. \& Marchand, C. (2010). Chem. Biol. 17, 421-433.

Sekgota, K. C., Majumder, S., Isaacs, M., Mnkandhla, D., Hoppe, H. C., Khanye, S. D., Kriel, F. H., Coates, J. \& Kaye, P. T. (2017). Bioorg. Chem. 75, 310-316.

Shahin, M. I., Roy, J., Hanafi, M., Wang, D., Luesakul, U., Chai, Y., Muangsin, N., Lasheen, D. S., Ella, D. A. A. E., Abouzid, K. A. \& Neamati, N. (2018). Eur. J. Med. Chem. 155, 516-530.

Sheldrick, G. M. (2008). Acta Cryst. A64, 112-122.

Sheldrick, G. M. (2015a). Acta Cryst. A71, 3-8.

Sheldrick, G. M. (2015b). Acta Cryst. C71, 3-8.

Spackman, M. A. \& Jayatilaka, D. (2009). CrystEngComm, 11, 19-32.

Spackman, M. A., McKinnon, J. J. \& Jayatilaka, D. (2008). CrystEngComm, 10, 377-388.

Turner, M. J., Grabowsky, S., Jayatilaka, D. \& Spackman, M. A. (2014). J. Phys. Chem. Lett. 5, 4249-4255.

Turner, M. J., McKinnon, J. J., Wolff, S. K., Grimwood, D. J., Spackman, P. R., Jayatilaka, D. \& Spackman, M. A. (2017). CrystalExplorer17. The University of Western Australia.

Turner, M. J., Thomas, S. P., Shi, M. W., Jayatilaka, D. \& Spackman, M. A. (2015). Chem. Commun. 51, 3735-3738.

Venkatesan, P., Thamotharan, S., Ilangovan, A., Liang, H. \& Sundius, T. (2016). Spectrochim. Acta Part A, 153, 625-636.

Xu, Z., Song, X. F., Hu, Y. Q., Qiang, M. \& Lv, Z. S. (2017). Eur. J. Med. Chem. 138, 66-71.

Zhang, G. F., Liu, X. F., Zhang, S., Pan, B. F. \& Liu, M. L. (2018). Eur. J. Med. Chem. 146, 599-612. 


\section{supporting information}

Acta Cryst. (2019). E75, 1411-1417 [https://doi.org/10.1107/S2056989019012283]

Crystal structure, Hirshfeld surface analysis and interaction energy and DFT studies of 2-chloroethyl 2-oxo-1-(prop-2-yn-1-yl)-1,2-dihydroquinoline-4carboxylate

Sonia Hayani, Yassir Filali Baba, Tuncer Hökelek, Fouad Ouazzani Chahdi, Joel T. Mague, Nada Kheira Sebbar and Youssef Kandri Rodi

Computing details

Data collection: APEX3 (Bruker, 2016); cell refinement: SAINT (Bruker, 2016); data reduction: SAINT (Bruker, 2016); program(s) used to solve structure: SHELXT (Sheldrick, 2015a); program(s) used to refine structure: SHELXL2018 (Sheldrick, 2015b); molecular graphics: DIAMOND (Brandenburg \& Putz, 2012); software used to prepare material for publication: SHELXTL (Sheldrick, 2008).

2-Chloroethyl 2-oxo-1-(prop-2-yn-1-yl)-1,2-dihydroquinoline-4-carboxylate

Crystal data

$\mathrm{C}_{15} \mathrm{H}_{12} \mathrm{ClNO}_{3}$

$M_{r}=289.71$

Monoclinic, $P 2_{1} / n$

$a=7.1809(2) \AA$

$b=21.4466(5) \AA$

$c=8.9173(2) \AA$

$\beta=92.784(2)^{\circ}$

$V=1371.70(6) \AA^{3}$

$Z=4$

Data collection

Bruker D8 VENTURE PHOTON 100 CMOS diffractometer

Radiation source: INCOATEC I $\mu \mathrm{S}$ micro-focus source

Mirror monochromator

Detector resolution: 10.4167 pixels $\mathrm{mm}^{-1}$

$\omega$ scans

Absorption correction: multi-scan

(SADABS; Krause et al., 2015)

Refinement

Refinement on $F^{2}$

Least-squares matrix: full

$R\left[F^{2}>2 \sigma\left(F^{2}\right)\right]=0.078$

$w R\left(F^{2}\right)=0.178$

$S=1.13$
$F(000)=600$

$D_{\mathrm{x}}=1.403 \mathrm{Mg} \mathrm{m}^{-3}$

$\mathrm{Cu} K \alpha$ radiation, $\lambda=1.54178 \AA$

Cell parameters from 6719 reflections

$\theta=4.1-69.9^{\circ}$

$\mu=2.53 \mathrm{~mm}^{-1}$

$T=150 \mathrm{~K}$

Plate, colourless

$0.19 \times 0.14 \times 0.01 \mathrm{~mm}$

$T_{\min }=0.64, T_{\max }=0.97$

10119 measured reflections

2555 independent reflections

2170 reflections with $I>2 \sigma(I)$

$R_{\text {int }}=0.047$

$\theta_{\max }=70.1^{\circ}, \theta_{\min }=4.1^{\circ}$

$h=-8 \rightarrow 8$

$k=-26 \rightarrow 25$

$l=-10 \rightarrow 10$

2555 reflections

181 parameters

0 restraints

Primary atom site location: dual space 
Secondary atom site location: difference Fourier map

Hydrogen site location: inferred from neighbouring sites

$\mathrm{H}$-atom parameters constrained

$$
\begin{aligned}
& w=1 /\left[\sigma^{2}\left(F_{\mathrm{o}}{ }^{2}\right)+(0.0332 P)^{2}+4.0657 P\right] \\
& \text { where } P=\left(F_{\mathrm{o}}^{2}+2 F_{\mathrm{c}}{ }^{2}\right) / 3 \\
& (\Delta / \sigma)_{\max }<0.001 \\
& \Delta \rho_{\max }=0.73 \mathrm{e} \AA^{-3} \\
& \Delta \rho_{\min }=-0.35 \mathrm{e} \AA^{-3}
\end{aligned}
$$

Special details

Geometry. All esds (except the esd in the dihedral angle between two 1.s. planes) are estimated using the full covariance matrix. The cell esds are taken into account individually in the estimation of esds in distances, angles and torsion angles; correlations between esds in cell parameters are only used when they are defined by crystal symmetry. An approximate (isotropic) treatment of cell esds is used for estimating esds involving l.s. planes.

Refinement. Refinement of $\mathrm{F}^{2}$ against ALL reflections. The weighted R-factor wR and goodness of fit $\mathrm{S}$ are based on $\mathrm{F}^{2}$, conventional R-factors $R$ are based on $F$, with $F$ set to zero for negative $F^{2}$. The threshold expression of $\mathrm{F}^{2}>2 \operatorname{sigma}\left(\mathrm{F}^{2}\right)$ is used only for calculating R-factors(gt) etc. and is not relevant to the choice of reflections for refinement. R-factors based on $\mathrm{F}^{2}$ are statistically about twice as large as those based on F, and R- factors based on ALL data will be even larger. Hatoms attached to carbon were placed in calculated positions $(\mathrm{C}-\mathrm{H}=0.95-0.99 \AA)$ and included as riding contributions with isotropic displacement parameters $1.2-1.5$ times those of the attached atoms. The largest peaks and holes in the final difference map are $<+/-1 \mathrm{e}^{-}-1 \% \mathrm{~A}^{-3}$ and are associated with the 2-chloroethylcarboxy group and may indicate a slight degree of disorder here but it was not considered serious enough to model.

Fractional atomic coordinates and isotropic or equivalent isotropic displacement parameters $\left(\AA^{2}\right)$

\begin{tabular}{lllll}
\hline & $x$ & $y$ & $z$ & $U_{\text {iso }} / U_{\text {eq }}$ \\
\hline C11 & $0.7800(2)$ & $0.24965(6)$ & $0.45136(18)$ & $0.0683(4)$ \\
O1 & $0.1693(4)$ & $0.43876(13)$ & $0.9233(3)$ & $0.0390(7)$ \\
O2 & $0.1917(5)$ & $0.33835(15)$ & $0.3272(4)$ & $0.0569(9)$ \\
O3 & $0.3893(5)$ & $0.30409(14)$ & $0.5116(4)$ & $0.0505(8)$ \\
N1 & $0.1864(4)$ & $0.50421(13)$ & $0.7226(3)$ & $0.0269(6)$ \\
C1 & $0.2615(5)$ & $0.46384(17)$ & $0.4782(4)$ & $0.0282(8)$ \\
C2 & $0.2997(5)$ & $0.47567(19)$ & $0.3269(4)$ & $0.0345(9)$ \\
H2 & 0.324683 & 0.441692 & 0.262595 & $0.041^{*}$ \\
C3 & $0.3014(5)$ & $0.5349(2)$ & $0.2715(4)$ & $0.0372(9)$ \\
H3 & 0.326460 & 0.541915 & 0.169253 & $0.045^{*}$ \\
C4 & $0.2661(5)$ & $0.58513(19)$ & $0.3654(4)$ & $0.0363(9)$ \\
H4 & 0.267501 & 0.626395 & 0.326807 & $0.044^{*}$ \\
C5 & $0.2290(5)$ & $0.57527(18)$ & $0.5145(4)$ & $0.0312(8)$ \\
H5 & 0.205814 & 0.609762 & 0.577824 & $0.037^{*}$ \\
C6 & $0.2256(5)$ & $0.51487(17)$ & $0.5719(4)$ & $0.0266(7)$ \\
C7 & $0.1967(5)$ & $0.44600(17)$ & $0.7888(4)$ & $0.0296(8)$ \\
C8 & $0.2365(5)$ & $0.39456(17)$ & $0.6907(4)$ & $0.0326(8)$ \\
H8 & 0.244434 & 0.353690 & 0.731581 & $0.039^{*}$ \\
C9 & $0.2627(5)$ & $0.40246(17)$ & $0.5429(4)$ & $0.0308(8)$ \\
C10 & $0.1343(5)$ & $0.55651(17)$ & $0.8183(4)$ & $0.0295(8)$ \\
H10A & 0.047696 & 0.584337 & 0.760268 & $0.035^{*}$ \\
H10B & 0.067963 & 0.540162 & 0.904796 & $0.035^{*}$ \\
C11 & $0.2966(6)$ & $0.59261(18)$ & $0.8741(4)$ & $0.0346(9)$ \\
C12 & $0.4275(7)$ & $0.6208(2)$ & $0.9178(5)$ & $0.0485(11)$ \\
H12 & 0.533984 & 0.643689 & 0.953389 & $0.058^{*}$ \\
C13 & $0.2778(6)$ & $0.34610(18)$ & $0.4461(5)$ & $0.0385(9)$ \\
C14 & $0.4018(8)$ & $0.2450(2)$ & $0.4316(6)$ & $0.0595(14)$ \\
& & & &
\end{tabular}




$\begin{array}{lllll}\text { H14A } & 0.286502 & 0.220384 & 0.441323 & 0.071^{*} \\ \text { H14B } & 0.419443 & 0.252540 & 0.323617 & 0.071^{*} \\ \text { C15 } & 0.5603(9) & 0.2122(2) & 0.4990(6) & 0.0629(14) \\ \text { H15A } & 0.559154 & 0.168527 & 0.463120 & 0.076^{*} \\ \text { H15B } & 0.551442 & 0.211642 & 0.609416 & 0.076^{*}\end{array}$

Atomic displacement parameters $\left(\AA^{2}\right)$

\begin{tabular}{|c|c|c|c|c|c|c|}
\hline & $U^{11}$ & $U^{22}$ & $U^{33}$ & $U^{12}$ & $U^{13}$ & $U^{23}$ \\
\hline Cl1 & $0.0708(9)$ & $0.0393(6)$ & $0.0940(11)$ & $0.0187(6)$ & $-0.0052(7)$ & $-0.0096(6)$ \\
\hline O1 & $0.0464(16)$ & $0.0416(15)$ & $0.0301(15)$ & $0.0056(13)$ & $0.0132(12)$ & $0.0061(12)$ \\
\hline $\mathrm{O} 2$ & $0.074(2)$ & 0.0488 (19) & 0.0469 (19) & $0.0006(17)$ & $-0.0037(17)$ & $-0.0143(15)$ \\
\hline $\mathrm{O} 3$ & $0.057(2)$ & $0.0357(16)$ & $0.060(2)$ & 0.0087 (14) & 0.0107 (16) & $-0.0126(14)$ \\
\hline N1 & $0.0262(15)$ & $0.0270(15)$ & $0.0282(16)$ & $0.0024(12)$ & $0.0081(12)$ & $-0.0009(12)$ \\
\hline $\mathrm{C} 1$ & $0.0206(16)$ & $0.0332(19)$ & 0.0314 (19) & $-0.0018(14)$ & $0.0064(14)$ & $-0.0014(15)$ \\
\hline $\mathrm{C} 2$ & $0.0276(19)$ & $0.047(2)$ & $0.030(2)$ & $-0.0039(17)$ & $0.0062(15)$ & $-0.0071(17)$ \\
\hline $\mathrm{C} 3$ & $0.033(2)$ & $0.051(2)$ & $0.028(2)$ & $-0.0076(18)$ & $0.0037(16)$ & $0.0055(17)$ \\
\hline $\mathrm{C} 4$ & $0.033(2)$ & $0.041(2)$ & $0.035(2)$ & $-0.0045(17)$ & $-0.0001(16)$ & $0.0091(17)$ \\
\hline $\mathrm{C} 5$ & $0.0264(18)$ & 0.0325 (19) & $0.035(2)$ & $-0.0008(15)$ & $0.0035(15)$ & $0.0018(16)$ \\
\hline C6 & $0.0194(16)$ & 0.0335 (19) & $0.0273(18)$ & 0.0005 (14) & $0.0058(13)$ & $0.0004(15)$ \\
\hline $\mathrm{C} 7$ & $0.0252(18)$ & 0.0302 (19) & $0.034(2)$ & $0.0011(14)$ & $0.0082(15)$ & $0.0029(15)$ \\
\hline $\mathrm{C} 8$ & 0.0317 (19) & 0.0285 (19) & $0.038(2)$ & $0.0020(15)$ & $0.0080(16)$ & $0.0044(16)$ \\
\hline C9 & $0.0249(18)$ & 0.0323 (19) & $0.036(2)$ & $0.0006(14)$ & $0.0088(15)$ & $-0.0020(16)$ \\
\hline $\mathrm{C} 10$ & $0.0287(18)$ & 0.0307 (19) & 0.0297 (19) & $0.0034(15)$ & $0.0076(15)$ & $-0.0025(15)$ \\
\hline $\mathrm{C} 11$ & $0.043(2)$ & $0.034(2)$ & $0.028(2)$ & 0.0003 (17) & $0.0101(17)$ & $-0.0039(16)$ \\
\hline $\mathrm{C} 12$ & $0.047(3)$ & $0.056(3)$ & $0.043(3)$ & $-0.009(2)$ & $0.006(2)$ & $-0.010(2)$ \\
\hline $\mathrm{C} 13$ & $0.038(2)$ & $0.030(2)$ & 0.049 (3) & $0.0004(17)$ & 0.0092 (19) & $-0.0001(18)$ \\
\hline C14 & $0.086(4)$ & $0.029(2)$ & $0.065(3)$ & $0.012(2)$ & $0.021(3)$ & $-0.005(2)$ \\
\hline $\mathrm{C} 15$ & $0.091(4)$ & $0.046(3)$ & $0.051(3)$ & $0.013(3)$ & 0.007 (3) & $0.002(2)$ \\
\hline
\end{tabular}

Geometric parameters $\left(\AA,{ }^{\circ}\right)$

\begin{tabular}{llll}
\hline $\mathrm{C} 11-\mathrm{C} 15$ & $1.838(6)$ & $\mathrm{C} 5-\mathrm{C} 6$ & $1.393(5)$ \\
$\mathrm{O} 1-\mathrm{C} 7$ & $1.235(5)$ & $\mathrm{C} 5-\mathrm{H} 5$ & 0.9500 \\
$\mathrm{O} 2-\mathrm{C} 13$ & $1.213(5)$ & $\mathrm{C} 7-\mathrm{C} 8$ & $1.445(5)$ \\
$\mathrm{O} 3-\mathrm{C} 13$ & $1.322(5)$ & $\mathrm{C} 8-\mathrm{C} 9$ & $1.351(5)$ \\
$\mathrm{O} 3-\mathrm{C} 14$ & $1.459(5)$ & $\mathrm{C} 8-\mathrm{H} 8$ & 0.9500 \\
$\mathrm{~N} 1-\mathrm{C} 7$ & $1.381(5)$ & $\mathrm{C} 9-\mathrm{C} 13$ & $1.492(5)$ \\
$\mathrm{N} 1-\mathrm{C} 6$ & $1.405(4)$ & $\mathrm{C} 10-\mathrm{C} 11$ & $1.465(5)$ \\
$\mathrm{N} 1-\mathrm{C} 10$ & $1.469(4)$ & $\mathrm{C} 10-\mathrm{H} 10 \mathrm{~A}$ & 0.9900 \\
$\mathrm{C} 1-\mathrm{C} 6$ & $1.409(5)$ & $\mathrm{C} 10-\mathrm{H} 10 \mathrm{~B}$ & 0.9900 \\
$\mathrm{C} 1-\mathrm{C} 2$ & $1.412(5)$ & $\mathrm{C} 11-\mathrm{C} 12$ & $1.169(6)$ \\
$\mathrm{C} 1-\mathrm{C} 9$ & $\mathrm{C} 12-\mathrm{H} 12$ & 0.9500 \\
$\mathrm{C} 2-\mathrm{C} 3$ & $\mathrm{C} 14-\mathrm{C} 15$ & $1.444(8)$ \\
$\mathrm{C} 2-\mathrm{H} 2$ & $1.437(5)$ & $\mathrm{C} 14-\mathrm{H} 14 \mathrm{~A}$ & 0.9900 \\
$\mathrm{C} 3-\mathrm{C} 4$ & $1.363(6)$ & $\mathrm{C} 14-\mathrm{H} 14 \mathrm{~B}$ & 0.9900 \\
$\mathrm{C} 3-\mathrm{H} 3$ & 0.9500 & $\mathrm{C} 15-\mathrm{H} 15 \mathrm{~A}$ & 0.9900 \\
$\mathrm{C} 4-\mathrm{C} 5$ & $1.396(6)$ & $\mathrm{C} 15-\mathrm{H} 15 \mathrm{~B}$ & 0.9900
\end{tabular}




\begin{tabular}{|c|c|c|c|}
\hline $\mathrm{C} 4-\mathrm{H} 4$ & 0.9500 & & \\
\hline $\mathrm{Cl} 1 \cdots \mathrm{O} 3$ & $3.110(3)$ & $\mathrm{C} 1 \cdots \mathrm{C} 6^{\mathrm{viii}}$ & $3.534(5)$ \\
\hline $\mathrm{C} 11 \cdots \mathrm{C} 12^{\mathrm{i}}$ & $3.629(5)$ & $\mathrm{C} 2 \cdots \mathrm{C} 6^{\mathrm{ii}}$ & $3.489(5)$ \\
\hline $\mathrm{C} 11 \cdots \mathrm{H} 12^{\mathrm{i}}$ & 2.75 & $\mathrm{C} 2 \cdots \mathrm{C} 10^{\text {viii }}$ & $3.388(5)$ \\
\hline $\mathrm{Cl} 1 \cdots \mathrm{H} 5^{\mathrm{ii}}$ & 3.03 & $\mathrm{C} 4 \cdots \mathrm{C} 7^{\text {viii }}$ & $3.597(5)$ \\
\hline $\mathrm{Cl} 1 \cdots \mathrm{H} 8^{\mathrm{iii}}$ & 2.96 & $\mathrm{C} 4 \cdots \mathrm{C} 9^{\mathrm{ii}}$ & $3.452(5)$ \\
\hline $\mathrm{O} 1 \cdots \mathrm{C} 10^{\mathrm{iv}}$ & $3.250(5)$ & $\mathrm{C} 5 \cdots \mathrm{C} 11$ & $3.241(5)$ \\
\hline $\mathrm{O} 1 \cdots \mathrm{C} 12^{\mathrm{v}}$ & $3.409(6)$ & $\mathrm{C} 5 \cdots C 9^{\text {viii }}$ & $3.575(5)$ \\
\hline $\mathrm{O} 1 \cdots \mathrm{C} 15^{\mathrm{vi}}$ & $3.406(5)$ & $\mathrm{C} 6 \cdots \mathrm{C}^{\mathrm{viii}}$ & 3.485 (4) \\
\hline $\mathrm{O} 2 \cdots \mathrm{C} 2$ & $3.045(5)$ & $\mathrm{C} 2 \cdots \mathrm{H} 10 \mathrm{~A}^{\mathrm{viii}}$ & 2.88 \\
\hline $\mathrm{O} 2 \cdots \mathrm{C} 15^{\mathrm{vii}}$ & $3.219(6)$ & $\mathrm{C} 5 \cdots \mathrm{H} 10 \mathrm{~A}$ & 2.61 \\
\hline $\mathrm{O} 3 \cdots \mathrm{Cl} 1$ & $3.110(3)$ & $\mathrm{C} 10 \cdots \mathrm{H} 5$ & 2.50 \\
\hline $\mathrm{O} 1 \cdots \mathrm{H} 10 \mathrm{~B}$ & 2.30 & $\mathrm{C} 11 \cdots \mathrm{H} 3^{\text {ix }}$ & 2.85 \\
\hline $\mathrm{O} 1 \cdots \mathrm{H} 10 \mathrm{~B}^{\mathrm{iv}}$ & 2.39 & $\mathrm{C} 11 \cdots \mathrm{H} 5$ & 2.72 \\
\hline $\mathrm{O} 1 \cdots \mathrm{H} 15 \mathrm{~A}^{\mathrm{vi}}$ & 2.46 & $\mathrm{C} 12 \cdots \mathrm{H} 14 \mathrm{~A}^{\mathrm{x}}$ & 2.95 \\
\hline $\mathrm{O} 2 \cdots \mathrm{H} 14 \mathrm{~B}$ & 2.46 & $\mathrm{C} 12 \cdots \mathrm{H} 2^{\mathrm{ii}}$ & 2.80 \\
\hline $\mathrm{O} 2 \cdots \mathrm{H} 2$ & 2.49 & $\mathrm{C} 12 \cdots \mathrm{H} 3^{\mathrm{ix}}$ & 2.93 \\
\hline $\mathrm{O} 2 \cdots \mathrm{H} 14 \mathrm{~A}$ & 2.80 & $\mathrm{C} 13 \cdots \mathrm{H} 2$ & 2.65 \\
\hline $\mathrm{O} 2 \cdots \mathrm{H} 15 \mathrm{~B}^{\mathrm{vii}}$ & 2.40 & $\mathrm{H} 5 \cdots \mathrm{H} 10 \mathrm{~A}$ & 2.10 \\
\hline $\mathrm{O} 2 \cdots \mathrm{H} 10 \mathrm{~A}^{\mathrm{viii}}$ & 2.49 & $\mathrm{H} 8 \cdots \mathrm{H} 15 \mathrm{~A}^{\mathrm{vi}}$ & 2.55 \\
\hline $\mathrm{O} 3 \cdots \mathrm{H} 8$ & 2.50 & & \\
\hline $\mathrm{C} 13-\mathrm{O} 3-\mathrm{C} 14$ & $115.2(4)$ & $\mathrm{C} 7-\mathrm{C} 8-\mathrm{H} 8$ & 118.8 \\
\hline $\mathrm{C} 7-\mathrm{N} 1-\mathrm{C} 6$ & $123.1(3)$ & $\mathrm{C} 8-\mathrm{C} 9-\mathrm{C} 1$ & $120.5(3)$ \\
\hline $\mathrm{C} 7-\mathrm{N} 1-\mathrm{C} 10$ & $116.9(3)$ & $\mathrm{C} 8-\mathrm{C} 9-\mathrm{C} 13$ & $118.7(3)$ \\
\hline $\mathrm{C} 6-\mathrm{N} 1-\mathrm{C} 10$ & $120.0(3)$ & $\mathrm{C} 1-\mathrm{C} 9-\mathrm{C} 13$ & $120.6(3)$ \\
\hline $\mathrm{C} 6-\mathrm{C} 1-\mathrm{C} 2$ & $118.5(3)$ & $\mathrm{C} 11-\mathrm{C} 10-\mathrm{N} 1$ & $112.3(3)$ \\
\hline $\mathrm{C} 6-\mathrm{C} 1-\mathrm{C} 9$ & $118.1(3)$ & $\mathrm{C} 11-\mathrm{C} 10-\mathrm{H} 10 \mathrm{~A}$ & 109.1 \\
\hline $\mathrm{C} 2-\mathrm{C} 1-\mathrm{C} 9$ & $123.4(3)$ & $\mathrm{N} 1-\mathrm{C} 10-\mathrm{H} 10 \mathrm{~A}$ & 109.1 \\
\hline $\mathrm{C} 3-\mathrm{C} 2-\mathrm{C} 1$ & $121.3(4)$ & $\mathrm{C} 11-\mathrm{C} 10-\mathrm{H} 10 \mathrm{~B}$ & 109.1 \\
\hline $\mathrm{C} 3-\mathrm{C} 2-\mathrm{H} 2$ & 119.4 & $\mathrm{~N} 1-\mathrm{C} 10-\mathrm{H} 10 \mathrm{~B}$ & 109.1 \\
\hline $\mathrm{C} 1-\mathrm{C} 2-\mathrm{H} 2$ & 119.4 & $\mathrm{H} 10 \mathrm{~A}-\mathrm{C} 10-\mathrm{H} 10 \mathrm{~B}$ & 107.9 \\
\hline $\mathrm{C} 2-\mathrm{C} 3-\mathrm{C} 4$ & $119.8(4)$ & $\mathrm{C} 12-\mathrm{C} 11-\mathrm{C} 10$ & $179.1(5)$ \\
\hline $\mathrm{C} 2-\mathrm{C} 3-\mathrm{H} 3$ & 120.1 & $\mathrm{C} 11-\mathrm{C} 12-\mathrm{H} 12$ & 180.0 \\
\hline $\mathrm{C} 4-\mathrm{C} 3-\mathrm{H} 3$ & 120.1 & $\mathrm{O} 2-\mathrm{C} 13-\mathrm{O} 3$ & $124.4(4)$ \\
\hline $\mathrm{C} 5-\mathrm{C} 4-\mathrm{C} 3$ & $120.5(4)$ & $\mathrm{O} 2-\mathrm{C} 13-\mathrm{C} 9$ & $124.6(4)$ \\
\hline $\mathrm{C} 5-\mathrm{C} 4-\mathrm{H} 4$ & 119.8 & $\mathrm{O} 3-\mathrm{C} 13-\mathrm{C} 9$ & $110.8(4)$ \\
\hline $\mathrm{C} 3-\mathrm{C} 4-\mathrm{H} 4$ & 119.8 & $\mathrm{C} 15-\mathrm{C} 14-\mathrm{O} 3$ & $106.6(5)$ \\
\hline $\mathrm{C} 4-\mathrm{C} 5-\mathrm{C} 6$ & $120.1(4)$ & $\mathrm{C} 15-\mathrm{C} 14-\mathrm{H} 14 \mathrm{~A}$ & 110.4 \\
\hline $\mathrm{C} 4-\mathrm{C} 5-\mathrm{H} 5$ & 119.9 & $\mathrm{O} 3-\mathrm{C} 14-\mathrm{H} 14 \mathrm{~A}$ & 110.4 \\
\hline $\mathrm{C} 6-\mathrm{C} 5-\mathrm{H} 5$ & 119.9 & $\mathrm{C} 15-\mathrm{C} 14-\mathrm{H} 14 \mathrm{~B}$ & 110.4 \\
\hline $\mathrm{C} 5-\mathrm{C} 6-\mathrm{N} 1$ & $120.7(3)$ & $\mathrm{O} 3-\mathrm{C} 14-\mathrm{H} 14 \mathrm{~B}$ & 110.4 \\
\hline $\mathrm{C} 5-\mathrm{C} 6-\mathrm{C} 1$ & $119.8(3)$ & $\mathrm{H} 14 \mathrm{~A}-\mathrm{C} 14-\mathrm{H} 14 \mathrm{~B}$ & 108.6 \\
\hline $\mathrm{N} 1-\mathrm{C} 6-\mathrm{C} 1$ & $119.5(3)$ & $\mathrm{C} 14-\mathrm{C} 15-\mathrm{Cl1}$ & $111.0(4)$ \\
\hline $\mathrm{O} 1-\mathrm{C} 7-\mathrm{N} 1$ & $121.4(3)$ & $\mathrm{C} 14-\mathrm{C} 15-\mathrm{H} 15 \mathrm{~A}$ & 109.4 \\
\hline $\mathrm{O} 1-\mathrm{C} 7-\mathrm{C} 8$ & $122.5(3)$ & $\mathrm{Cl1}-\mathrm{C} 15-\mathrm{H} 15 \mathrm{~A}$ & 109.4 \\
\hline $\mathrm{N} 1-\mathrm{C} 7-\mathrm{C} 8$ & $116.1(3)$ & $\mathrm{C} 14-\mathrm{C} 15-\mathrm{H} 15 \mathrm{~B}$ & 109.4 \\
\hline
\end{tabular}




$\begin{array}{llll}\mathrm{C} 9-\mathrm{C} 8-\mathrm{C} 7 & 122.4(3) & \mathrm{C} 11-\mathrm{C} 15-\mathrm{H} 15 \mathrm{~B} & 109.4 \\ \mathrm{C} 9-\mathrm{C} 8-\mathrm{H} 8 & 118.8 & \mathrm{H} 15 \mathrm{~A}-\mathrm{C} 15-\mathrm{H} 15 \mathrm{~B} & 108.0 \\ \mathrm{C} 6-\mathrm{C} 1-\mathrm{C} 2-\mathrm{C} 3 & -0.3(5) & \mathrm{O} 1-\mathrm{C} 7-\mathrm{C} 8-\mathrm{C} 9 & 178.7(4) \\ \mathrm{C} 9-\mathrm{C} 1-\mathrm{C} 2-\mathrm{C} 3 & -178.4(4) & \mathrm{N} 1-\mathrm{C} 7-\mathrm{C} 8-\mathrm{C} 9 & 0.1(5) \\ \mathrm{C} 1-\mathrm{C} 2-\mathrm{C} 3-\mathrm{C} 4 & 0.4(6) & \mathrm{C} 7-\mathrm{C} 8-\mathrm{C} 9-\mathrm{C} 1 & 3.3(6) \\ \mathrm{C} 2-\mathrm{C} 3-\mathrm{C} 4-\mathrm{C} 5 & -0.1(6) & \mathrm{C} 7-\mathrm{C} 8-\mathrm{C} 9-\mathrm{C} 13 & -171.9(3) \\ \mathrm{C} 3-\mathrm{C} 4-\mathrm{C} 5-\mathrm{C} 6 & -0.4(6) & \mathrm{C} 6-\mathrm{C} 1-\mathrm{C} 9-\mathrm{C} 8 & -2.3(5) \\ \mathrm{C} 4-\mathrm{C} 5-\mathrm{C} 6-\mathrm{N} 1 & -179.4(3) & \mathrm{C} 2-\mathrm{C} 1-\mathrm{C} 9-\mathrm{C} 8 & 175.9(4) \\ \mathrm{C} 4-\mathrm{C} 5-\mathrm{C} 6-\mathrm{C} 1 & 0.5(5) & \mathrm{C} 6-\mathrm{C} 1-\mathrm{C} 9-\mathrm{C} 13 & 172.9(3) \\ \mathrm{C} 7-\mathrm{N} 1-\mathrm{C} 6-\mathrm{C} 5 & -174.3(3) & \mathrm{C} 2-\mathrm{C} 1-\mathrm{C} 9-\mathrm{C} 13 & -9.0(5) \\ \mathrm{C} 10-\mathrm{N} 1-\mathrm{C} 6-\mathrm{C} 5 & 4.7(5) & \mathrm{C} 7-\mathrm{N} 1-\mathrm{C} 10-\mathrm{C} 11 & 99.5(4) \\ \mathrm{C} 7-\mathrm{N} 1-\mathrm{C} 6-\mathrm{C} 1 & 5.7(5) & \mathrm{C} 6-\mathrm{N} 1-\mathrm{C} 10-\mathrm{C} 11 & -79.6(4) \\ \mathrm{C} 10-\mathrm{N} 1-\mathrm{C} 6-\mathrm{C} 1 & -175.2(3) & \mathrm{C} 14-\mathrm{O} 3-\mathrm{C} 13-\mathrm{O} 2 & -0.9(6) \\ \mathrm{C} 2-\mathrm{C} 1-\mathrm{C} 6-\mathrm{C} 5 & -0.2(5) & \mathrm{C} 14-\mathrm{O} 3-\mathrm{C} 13-\mathrm{C} 9 & 175.3(4) \\ \mathrm{C} 9-\mathrm{C} 1-\mathrm{C} 6-\mathrm{C} 5 & 178.0(3) & \mathrm{C} 8-\mathrm{C} 9-\mathrm{C} 13-\mathrm{O} 2 & 131.0(5) \\ \mathrm{C} 2-\mathrm{C} 1-\mathrm{C} 6-\mathrm{N} 1 & 179.7(3) & \mathrm{C} 1-\mathrm{C} 9-\mathrm{C} 13-\mathrm{O} 2 & -44.2(6) \\ \mathrm{C} 9-\mathrm{C} 1-\mathrm{C} 6-\mathrm{N} 1 & -2.1(5) & \mathrm{C} 8-\mathrm{C} 9-\mathrm{C} 13-\mathrm{O} 3 & -45.2(5) \\ \mathrm{C} 6-\mathrm{N} 1-\mathrm{C} 7-\mathrm{O} 1 & 176.8(3) & \mathrm{C} 1-\mathrm{C} 9-\mathrm{C} 13-\mathrm{O} 3 & 139.6(4) \\ \mathrm{C} 10-\mathrm{N} 1-\mathrm{C} 7-\mathrm{O} 1 & -2.3(5) & \mathrm{C} 13-\mathrm{O} 3-\mathrm{C} 14-\mathrm{C} 15 & 166.2(4) \\ \mathrm{C} 6-\mathrm{N} 1-\mathrm{C} 7-\mathrm{C} 8 & -4.7(5) & \mathrm{O} 3-\mathrm{C} 14-\mathrm{C} 15-\mathrm{Cl1} & -70.8(5) \\ \mathrm{C} 10-\mathrm{N} 1-\mathrm{C} 7-\mathrm{C} 8 & 176.2(3) & & \end{array}$

Symmetry codes: (i) $-x+3 / 2, y-1 / 2,-z+3 / 2$; (ii) $-x+1,-y+1,-z+1$; (iii) $x+1 / 2,-y+1 / 2, z-1 / 2$; (iv) $-x,-y+1,-z+2$; (v) $-x+1,-y+1,-z+2$; (vi) $x-1 / 2$, $-y+1 / 2, z+1 / 2$; (vii) $x-1 / 2,-y+1 / 2, z-1 / 2$; (viii) $-x,-y+1,-z+1$; (ix) $x, y, z+1$; (x) $-x+1 / 2, y+1 / 2,-z+3 / 2$.

Hydrogen-bond geometry $\left(\AA,{ }^{\circ}\right)$

\begin{tabular}{lllll}
\hline$D-\mathrm{H} \cdots A$ & $D-\mathrm{H}$ & $\mathrm{H} \cdots A$ & $D \cdots A$ & $D-\mathrm{H} \cdots A$ \\
\hline $\mathrm{C} 10-\mathrm{H} 10 A \cdots \mathrm{O} 2^{\text {viii }}$ & 0.99 & 2.49 & $3.458(5)$ & 167 \\
$\mathrm{C} 10-\mathrm{H} 10 B \cdots \mathrm{O} 1^{\text {iv }}$ & 0.99 & 2.39 & $3.250(4)$ & 145 \\
$\mathrm{C} 15-\mathrm{H} 15 A \cdots \mathrm{O} 1^{\text {iii }}$ & 0.99 & 2.46 & $3.406(6)$ & 159 \\
$\mathrm{C} 15-\mathrm{H} 15 B \cdots \mathrm{O} 2^{\text {xi }}$ & 0.99 & 2.40 & $3.219(6)$ & 140
\end{tabular}

Symmetry codes: (iii) $x+1 / 2,-y+1 / 2, z-1 / 2$; (iv) $-x,-y+1,-z+2$; (viii) $-x,-y+1,-z+1$; (xi) $x+1 / 2,-y+1 / 2, z+1 / 2$. 